1998

\title{
The Political Economy of Canadian Legal Education
}

Harry W. Arthurs

Osgoode Hall Law School of York University, harthurs@osgoode.yorku.ca

Source Publication:

Journal of Law and Society. Volume 25 (1998), p. 14-32.

Follow this and additional works at: https://digitalcommons.osgoode.yorku.ca/scholarly_works c) (i) $(9)$

This work is licensed under a Creative Commons Attribution-Noncommercial-No Derivative Works 4.0 License.

\section{Recommended Citation}

Arthurs, Harry W. "The Political Economy of Canadian Legal Education." Journal of Law and Society 25 (1998): 14-32.

This Article is brought to you for free and open access by the Faculty Scholarship at Osgoode Digital Commons. It has been accepted for inclusion in Articles \& Book Chapters by an authorized administrator of Osgoode Digital Commons. 


\section{HEINONLINE}

Citation: 25 J.L. \& Soc'y 141998

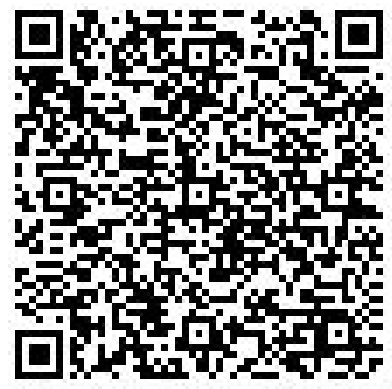

Content downloaded/printed from

HeinOnline (http://heinonline.org)

Thu Jun 4 11:23:29 2015

-- Your use of this HeinOnline PDF indicates your acceptance of HeinOnline's Terms and Conditions of the license agreement available at http://heinonline.org/HOL/License

-- The search text of this PDF is generated from uncorrected OCR text.

-- To obtain permission to use this article beyond the scope of your HeinOnline license, please use:

https://www.copyright.com/ccc/basicSearch.do? \&operation $=$ go\&search Type $=0$ \&lastSearch $=$ simple\&all $=$ on\&titleOrStdNo=0263-323X 


\title{
The Political Economy of Canadian Legal Education
}

\author{
H.W. ARTHURS*
}

The political economy of Canadian legal education is characterized by conflicts over resources, values, and interests. These conficts manifest themselves in divergences between faculty and students over issues of law school governance and politics, in the sometimes incompatible demands placed upon law schools by the legal profession and the university, in the intramural politics of class, race, and gender, and in rivalry among competing bodies of legal knowledge. Most importantly, the New Economy is reshaping legal education because the restructuring of Canada's society, economy, and polity is undermining the position and power of both the universities and the profession.

\section{INTRODUCTION AND HISTORICAL BACKGROUND}

The central premise of this essay is that legal education is lodged in a political economy whose contending forces shape universities, the legal profession and, of course, the encompassing society, economy, culture, and polity. Hence, legal education is not an autonomous regime capable of defining and redefining itself from within, in response to national reports, the prescriptions of professional bodies, decanal visions or even the initiatives of a reformist professoriate - though all of these make their contribution.

A brief glance at the history of Canadian legal education reinforces the point - or would if there were such a history to be glanced at.' Alas, the definitive history of Canadian legal education has yet to be written; nor given the decentralized nature of Canada, is it ever likely to be. Education,

* Osgoode Hall Law School, York University, 4700 Keele St., Toronto, Canada M3J 1 P3

I should like to express my thanks to Raziel Zisman for his able research assistance.

1 Indeed, there was not much history written about anything legal in Canada until the 1970s and 1980 s, other than a few legal-historical works by judges of an antiquarian bent, see, for example, W. Riddell, The Bar and the Courts of the Province of Upper Canada, or Ontario (1928). 
the administration of justice, and the regulation of professional bodies are matters within the constitutional competence of provinces, not the national government. The centrifugal force of the constitution reinforces, and is reinforced by, Canada's bisystemic and bilingual character, its demography, and its geography. Differing rates of political, economic, professional, and educational development in each province, and the effect of local circumstances and personalities in what were often relatively small and new communities also helped to ensure that each law school followed a somewhat different path of development. Thus, there is no such thing as a history of Canadian legal education, strictly speaking - only a history of legal education in Quebec, Nova Scotia or Manitoba.

On the other hand, certain common themes seem to recur. First, legal education in Canada's provinces comprised a succession of missed opportunities and noble failures. ${ }^{2}$ Second, the profession exercised overt control over legal education in some provinces, and acted more subtly in others; but its influence was pretty much dominant until well after the Second World War. Third, during this period, the Canadian legal academic community remained tiny - a few full-time academics in each faculty, less than fifty across the country by 1950 , barely one hundred by 1960 . And finally, its collective scholarly output was lamentably meagre and mostly pedestrian. ${ }^{3}$

These themes converge in the dramatic and well-documented controversy surrounding Osgoode Hall Law School in Ontario. Founded, after several false starts, in 1889 with the aspiration of becoming 'the Harvard of the North' (another recurring theme: the influence of the United States of America), it soon became the largest common law school in the country. But it was not a distinguished institution: it was ruled with a heavy hand by the Benchers of the Law Society of Upper Canada, ${ }^{4}$ operated as a doppelganger to a system of articling (apprenticeship), had low admissions standards, was retrograde in its curriculum, and lacked sufficient faculty, classrooms, and library facilities. In 1949, the law school's tiny staff of determined and able full-time academics sought to establish its control over curriculum and teaching methods. These academic pretensions were derided

2 See, for example, B. Baker, 'Legal Education in Upper Canada 1785-1889: The Law Society as Educator' in Essays in the History of Canadian Law, ed. D. Flaherty (1983); J. McLaren, 'The History of Legal Education in Common Law Canada' in Legal Education in Canada, eds. R. Matas and D. McCawley (1987); W. Pue, 'Common Law Legal Education in Canada's Age of Soap, Light and Water' (1996) 23 Manitoba Law J. 654; D. Howes, 'The Origin and Demise of Legal Education in Quebec (Or Hercules Bound)' (1989) 38 University of New Brunswick Law J. 127.

3 M. Cohen, 'The Condition of Legal Education in Canada' (1950) 28 Cdn. Bar Rev. 267; F. Scott (chair), 'Report of the Committee on Legal Research' (1956) 34 Cdn. Bar Rev. 999.

4 Ontario was known as Upper Canada prior to Confederation in 1867; the Law Society continues to use its pre-Confederation name. See C. Moore, The Law Society of Upper Canada and Ontario's Lawyers, 1797-1997 (1997).

5B. Bucknell, T. Baldwin, and D. Lakin, 'Pedants, Practitioners and Prophets: Legal 
by the conservative governing body; their initiative was rebuffed; and they resigned en masse to join the School of Law of the nearby University of Toronto, which did not confer professional credentials. From this vantage point, they relentlessly attacked their former school and its proprietors; by 1958 , they had succeeded in breaking the Law Society's monopoly over legal education in the province. ${ }^{5}$

The immediate consequence of this success was a proliferation of university law schools in Ontario, the largest province, and ultimately, in 1968, the Law Society's transfer of Osgoode Hall Law School to a more conventional and congenial setting at York University. ${ }^{6}$ These developments were to have critical consequences well beyond Ontario. The fact that Canada's largest and most influential legal profession had significantly modified its claims to dictate legal curriculum and pedagogy constituted a precedent of some importance in other provinces whose professional governing bodies continued to exercise de facto or de jure control. The proliferation of law schools in Ontario and across Canada, and significant curriculum reform at the reconstructed Osgoode Hall Law School and elsewhere, produced a dramatic swelling of faculty ranks and - for the first time in Canada's history - something like a critical mass of legal academics.

The timing of these events was crucial. The decade from the late 1950s through to the late 1960s was a transformative moment for Canada, for higher education generally, for law, and for legal education and scholarship. During this period, at the height of a prolonged post-war boom fuelled by immigration and foreign investment, Canada rapidly urbanized and shook off the last vestiges of its colonial past. Quebec's 'quiet revolution', Ontario's industrial expansion, the growth of resource-based industries in western Canada, and other projects of social and economic modernization proceeded in tandem with the growth of a welfare state and of state-supported cultural institutions and industries. Universities were part of this project of modernization, and expanded rapidly to provide not only highly skilled personnel for the new economy and state structures, but also the intellectual and institutional underpinnings of an unprecedented attempt to define Canadian, provincial, and community identities. ${ }^{7}$ The legal profession also experienced enormous growth and affluence, benefiting from economic expansion, the rise of the interventionist state, and a new sense of the possibilities and responsibilities of legal practice. And finally law itself began

5 B. Bucknell, T. Baldwin, and D. Lakin, 'Pedants, Practitioners and Prophets: Legal Education at Osgoode Hall to 1957' (1968) 6 Osgoode Hall Law J. 137; C. Kyer and J. Bickenbach, The Fiercest Debate: Cecil A. Wright, The Benchers, and Legal Education in Ontario 1923-1957 (1987).

6 H. Arthurs, 'Osgoode Hall Law School of York University' (1967) 17 University of Toronto Law J. 194.

7 To Know Ourselves - Report of the Commission on Canadian Studies (the Symons report) (1974). 
to change: beginning in the 1960 s, many Canadian jurisdictions introduced legal aid programmes, established law reform and human rights commissions, reformed the governance of the legal profession, and began to think seriously about civil liberties, welfare rights, and environmental law.

These dramatic transformations in the economic, social, and cultural life of the country, in the role of law and the legal profession, and in Canadian academic institutions, left their mark on law faculties. A new generation of legal academics with graduate degrees, training in the social sciences, and activist ambitions soon outnumbered the small cadre of black-letter scholars and part-time practitioners which had dominated most law schools. New pedagogies, curriculums, and research priorities were introduced. Law professors began to busy themselves inside and outside academe with a wide range of both critical and constructive projects of research and reform. Their new status and influence were symbolized by a coincidence which would have been unthinkable a few years earlier: in 1973 the Prime Minister, Minister of Justice, and Chief Justice of Canada were all former law professors.

These developments seemed to presage a revolution in Canadian legal education and scholarship. However, as things turned out, that revolution was less ambitious and successful than might have been predicted. This was the conclusion, at least, of Law and Learning, a comprehensive 1983 report on Canadian legal research and education. ${ }^{8}$ That report, and its accompanying research studies, concluded that in the heady atmosphere of the 1960s, law schools had launched themselves on the project of 'offering a legal education that is humane and professional, rather than narrowly vocational' by combining three elements: 'learning legal rules ...; learning legal skills; [and] developing a humane perspective on law, and a deeper understanding of law as a social phenomenon and an intellectual discipline'. ${ }^{9}$ However, the fact that these elements were . . . arranged in no fixed proportion or sequence ... within an eclectic, optional curriculum' resulted in serious under-achievement:

The basic problem of legal education is that it espouses a broad range of goals and has opted for no specific structure to achieve any of them. As a result, professional formation - undoubtedly the primary objective of Canadian law schools - is neither as effectively professional nor as broad and humane as it aspires to be. Scholarly or intellectual legal study is diluted and marginalized by the predominance of professional concerns. ${ }^{10}$

8 Consultative Group on Research and Education in Law, Law and Learning (1983). The study was co-sponsored by the Social Sciences and Humanities Research Council of Canada, the Committee of Canadian Law Deans, and the Association of Canadian Law Teachers. I was chair of the Consultative Group and principal author of its report.

9 id., p. 47.

10 id., p. 153. 
To overcome this problem, the report recommended a strategy of 'genuine pluralism' in law schools, based on a 'clear and explicit statement' of objectives:

Law faculties should substitute for their present eclectic curriculums a series of clearly defined alternatives based on intellectual insights, social goals, pedagogic strategies, or professional specialties ... Among the alternatives offered should be clearly defined scholarly programs leading to a first degree in law ..."

This latter recommendation, for a specifically scholarly education in law, reflects the central conviction of Law and Learning:

... [Scholarly] studies cannot be expected to develop while they are a peripheral interest of students and faculty members who are chiefly preoccupied with preparation for professional practice. As long as the scholarly study of law does not develop, the quantity and quality of legal scholarship are unlikely to improve significantly ... The intellectual training and career circumstances of legal researchers have not helped to give shape and direction to legal research . . .12

Given the strategic priority attached to the intellectual dimension of legal education, the report made a number of recommendations designed to ensure the better preparation of legal intellectuals, and to improve the quality, quantity, and diversity of legal scholarship. These changes, it was hoped, would not only protect the minority of students with specific intellectual goals and career objectives but would also, in the end, benefit the majority who were intending practitioners.

The post-history of Law and Learning is instructive. It was received with modest enthusiasm in Canada, although rather more abroad..$^{13}$ No law faculty actually privileged or protected students with intellectual interests. And while the Canadian law teachers now produce more fundamental and interdisciplinary research, and while graduate programmes in law have expanded and research centres have proliferated, it is by no means clear that Law and Learning was the proximate cause of such changes. At most, the report identified, legitimated, reinforced, and accelerated changes which were largely attributable to the transformation of Canadian society especially through the 1960s. However, as that transformation ran its course and as counter-influences developed, the momentum of reform in legal education slowed, and its future direction became contested.

This brings us to a crucial weakness of Law and Learning, a weakness it shares with most reports on legal education. It recorded and analysed the recent history of Canadian legal education with reasonable accuracy. It offered a plausible critique of existing structures and strategies. But it did not adequately investigate the political economy which had produced those

11 id., p. 154.

12 id., pp. 153-4.

13 J. Schlegel, 'Law and Learning' (1984) Stanford Law Rev. 1517. 
structures and strategies, and consequently did not accurately anticipate future developments. ${ }^{14}$ This essay is an attempt - fifteen years on - to address issues which Law and Learning left largely unexamined.

\section{GOVERNANCE AND POLITICS: FACULTY AND STUDENTS}

Prior to the 1960s, as noted, legal education was dominated by the profession in at least three senses. It was largely education by the profession: given the small number of full-time legal academics, much (sometimes most) instruction was offered by practising lawyers. To some extent, it was education in the profession: in all provinces, articling remained a strong component of the process of professional formation; in several - notoriously Ontario - only graduates of the profession's own law school could be admitted to practise; and almost everywhere, the profession played a formal or informal role in the governance of the local law school. And with some honourable exceptions, it was largely education for the profession: even the most spectacular upheaval of the period, the Osgoode Hall crisis of 1949, was prompted by a dispute over whether academics or the Bar knew best how to educate future practitioners.

Thus, until the 1960s, there was little occasion to be concerned about the internal governance of legal education. But occasion soon arose. In law schools, as elsewhere in the university and in society generally, the 1960s were a moment of upheaval. Traditional values and the institutions through which they were conveyed were under attack. By the end of the decade, the profession's role in society, its recruitment policies, its culture and governance had become matters of vigorous debate, especially in the law schools which were - how odd it now seems! - mapped as commanding heights whose seizure would transform the legal system and all of its emanations, if not society in general. One characteristic passion of the period, especially in Canada, was the democratization of universities and their faculties, initially by giving the professoriate the dominant voice in academic decision making, and subsequently by extending participation rights to students, even in such important matters as curriculum and faculty appointments. ${ }^{15}$ Closely linked to this development was the release of students from institutionalized constraints such as structured curricula and inflexible, authoritarian forms of pedagogy and academic evaluation. These reforms appealed not only to students, but also to young faculty members who believed that students would use their new-found freedom wisely, in ways which supported their own reformist aspirations.

14 H. Glasbeek and R. Hasson, 'Some Reflections on Legal Education' (1987) 50 Modern Law Rev. 777 had prophesied as much.

15 University Governance in Canada (the Duff-Berdahl report) (1966). 
Those aspirations were in part procedural, in the sense that young professors wished to operate free of professional requirements, ${ }^{16}$ the professional ethos of law faculties, or the authority of deans and senior professors. However, the aspirations were substantive as well. The professoriate sought to undermine the very basis of professional monopoly and power: its distinctive forms of knowledge. Despite occasional flirtations with philosophy and political science as early as the nineteenth century, ${ }^{17}$ Canadian legal education and scholarship had never really experienced the equivalent of the American realist revolution. This is hardly surprising, given the paucity of revolutionaries and their precarious perch in professionallydominated law schools. The new, self-confident academics saw themselves as agents of change. They wanted to use the social sciences to overthrow the profession's intellectual orthodoxy, the positivist school of black-letter law, and to redefine the mission of law schools. That mission, they contended, was not merely to replicate the profession, but to transform it; and not merely to transform it but to develop new empirical and critical perspectives on law, the legal system, and the profession; and not merely to develop these new perspectives but to share them with present and future policy makers, scholars, administrators, and informed citizens in all walks of life. The movement to democratize the governance of law schools, then, was part of a larger project of transforming law as an intellectual discipline, as a profession, and as a technique of social ordering.

However, these two motivations - democratization for its own sake, and as part of a larger transformative strategy - diverged. This divergence largely shaped law school politics of the period. Students - even many who considered themselves politically and intellectually radical - tended to see themselves as legal practitioners, albeit with new ideals and in the service of a new clientele. Consequently, they wanted law schools to equip them with the skills and knowledge necessary to achieve their professional objectives. Some law schools were able to accommodate this demand by establishing legal clinics, which combined skills training and social activism with a strong intellectual component. However, such programmes did not satisfy the new legal intelligentsia which wanted to reconceptualize law in both a systemic

16 While each provincial Law Society is free to determine which students qualify for admission as a result of having completed an 'approved' LLB course, the requirements of the Law Society of Upper Canada have national salience because so many students ultimately gravitate to Ontario. Its requirements are minimal: law schools must offer three years of full-time instruction comprising seven compulsory courses (real and personal property, contracts, torts, criminal law, civil procedure, constitutional law) and twenty-five additional courses which must be offered 'regularly' to students 'on a required or an optional basis' in the discretion of the 'academic planning authority' of each law school. Law schools must have at least five full-time staff; their recommended maximum teaching load is six hours per week; and library facilities must be 'adequate'.

17 R.St.J. Macdonald, 'Maximilien Bibaud, 1823-1887: The Pioneer Teacher of International Law in Canada' (1988) 11 Dalhousie Law J. 721; D. Stanley, ' Richard Chapman Weldon 1849-1925 - Fact, Fiction and Enigma' (1989) 12 Dalhousie Law J. 539. 
and substantive sense, a daunting task - as Law and Learning suggested for which most of its members were not well prepared.

Within the political economy of law schools, this conflict took the form of contestations over the allocation of resources. Faculty time and energy devoted to research was not devoted to teaching, community education or public advocacy - activities which students tended to value highly. When the first, admittedly meagre, fruits of critical scholarship began to ripen in the classroom, as sociology, history, and politics displaced legal doctrine, as more and more faculty members introduced new interdisciplinary offerings, students made their displeasure clear. They voted against these innovations in faculty council debates, ignored them when selecting optional courses, and if enrolled, passively resisted them by not taking them seriously. Likewise, students often favoured the appointment of new faculty recruits with apparent promise as teachers and mentors rather than those who displayed the most impressive intellectual credentials.

In sum, students tended to be a political drag on the intellectual revolution in Canadian law faculties. While eager to gain the democratic right to decide things for themselves, they were not much inclined to exercise this right to explore the foundations and frontiers of law. And to anticipate a point which will be made later, when the idealism of the 1960s was ultimately replaced by neo-conservatism and market discipline in the 1980s and 1990s, students began to reconceptualize themselves as consumers, with consumers' motivations and consumers' rights.

\section{THE POLITICS OF BORDERLANDS: THE PROFESSION AND THE UNIVERSITY}

Legal education is not terra nullius - territory unclaimed by any legitimate power. On the contrary: as Law and Learning insisted, it is located in the borderlands between two powerful suzerains, the higher education sector and the legal profession. Each of these, to be sure, is less a single state than a congeries of interests, ideologies, and institutions. None the less, when either asserts its claims, legal education becomes contested terrain.

If the profession - the governing body, the major law firms, the bar association, the alumni - becomes convinced that law schools should concern themselves with technical competence, moral tutelage, or the deployment of their graduates elsewhere than in private practice, law schools are likely to respond by increasing the number, length or content of 'core' courses (deemed, with no good reason save history, indispensable for the practice of law) and of specialized or advanced courses with obvious professional salience or a skills-training component, by reducing theoretical and interdisciplinary seminars and support for social activism, and by introducing counselling programmes designed to shift law graduates to other career options. 
If, on the other hand, universities - the education ministry, senior academic administrators, the Senate - insist that law professors conform to university- or system-wide expectations of scholarly productivity, meet high standards of pedagogic competence, and perform their fair share of university service, a different set of institutional adjustments will likely occur. These may include rewards and incentives for faculty members who win grants and publish prolifically, better support for research centres, greater investment in teaching technology, pedagogic training, and the systematic assessment of teaching, or more law professors 'volunteering' for university committees.

Of course, pressures from the profession and the university only rarely arrive in the form of explicit prescriptions or even clearly articulated requests. What the profession wants from law schools it can generally secure by subtle signals: after all, most students and some faculty members identify with the profession's aspirations and interests, self-image, and world-view. If a governing body ruminates on the increase of malpractice claims involving young practitioners, if it becomes common knowledge that litigators are undertaking more alternative dispute resolution, if the Attorney-General announces a reform of family property legislation, it is entirely predictable that someone will propose or demand that law schools should alter their curricula or teaching methods accordingly. Indeed, members of the faculty with relevant interest or expertise will themselves frequently initiate proposals for change which they justify on the basis of a new public or professional 'need', reinforced by the suggestion that if the law school does not rise to the occasion, it is likely to face professional intervention. Far from resisting such initiatives as unworthy of an educational institution, students tend to support them, imagining that in doing so they are improving their own marketability and professional competence.

Similarly, law schools seldom receive explicit instructions from university authorities. Rather, they wish to appear to be responsive to general university policies. The reason is simple: if they fail to adhere to standards for promotion and tenure, their new recruits will not pass muster; if they fail to recruit international students, their budgets may be cut; but if they can respond to policies in a distinctive 'professional' mode, they can continue to do pretty much as they please. However, margins for deviation may be diminishing. Pressed to ensure greater accountability to government and 'consumers', universities are subjecting all units - including law schools to periodic quality reviews, requiring them to produce standard data to support large-scale academic planning processes, and helping them to meet the criteria which drive such exercises. ${ }^{18}$ And here again influences are often

18 Maclean's Magazine, which ranks the undergraduate programmes of Canadian universities, introduced a 'league table' of law schools in 1997. 
more subtle. As many law professors come to share credentials, intellectual interests, and socializing experiences with other academics, they are likely to seek to reproduce prevailing teaching techniques, intellectual and political agendas, and academic cultures within law faculties.

Legal education, then, remains subject to influences emanating both from the profession and from the university. Although these influences seldom take the form of explicit directions, law schools respond to them in part to avoid negative consequences, in part to gain institutional advantages, but in part because internal constituencies align themselves opportunistically with or against the profession or the university. Thus, the internal political dynamic of Canadian law schools is often destabilized by the competing visions of legal education of its 'suzerains'.

Of course, destabilization is not inevitable: some versions of the academic enterprise are more acceptable to the profession than others; some universities are willing, even eager, that their law schools should be held in high repute by the Bar, an affluent and influential sector of the community; some law schools manage to achieve at least the appearance of a balance between the divergent perspectives and their respective adherents. But in the end, the two visions are different: at any given moment, they do not project equal power and influence, and whichever is ascendant in a particular law school will shape its teaching programme and intellectual ethos.

\section{THE POLITICS OF CLASS, RACE, AND GENDER}

In the proto-revolutionary atmosphere of the 1960 s, Canadian law schools became - were forced to become - aware of two linked paradoxes: although the legal profession's claim to its monopoly rested in part on its defence of equality before the law, the profession itself was not itself an exemplar of egalitarian virtue; and although within the profession, academic voices were amongst the loudest advocates of the egalitarian principle, the academy had also failed to ensure equal access to legal education - and legal practice regardless of race, gender or class.

Responses were not long in coming. Articles began to document and denounce the Bar's failures and those of legal academe as well. ${ }^{19}$ Law schools established community clinics to take up the challenge of delivering legal services to the disadvantaged, and of training lawyers for careers as their advocates. ${ }^{20}$ Courses on the rights of the poor, consumers, women, and racial

19 See, for example, H. Arthurs, L. Taman, J. Williams, 'The Toronto Legal Profession: An Exploratory Survey' (1971) 21 University of Toronto Law J. 498; L. Dranoff, 'Women as Lawyers in Toronto' (1972) 10 Osgoode Hall Law J. 177.

20 N. Gold, 'Legal Education, Law and Justice: The Clinical Experience' (1979) 44 Saskatoon Law Rev. 97; M.J. Mossman, 'Community Legal Clinics in Ontario' (1983) 3 Windsor Yearbook of Access to Justice 375. 
minorities effloresced modestly (or not so modestly, in the view of conservative lawyers). ${ }^{21}$ One new law school made an explicit and controversial commitment to popular and democratic education in law. ${ }^{22}$ Mandated by an unexpectedly liberal Law Society report, ${ }^{23}$ Ontario law faculties began to admit mature students, including many individuals who had been prevented by socio-economic disadvantages from pursuing normal pre-law studies. New federal funding assisted law schools in seeking out and admitting aboriginal students, especially graduates of a 'head start' programme at the University of Saskatchewan, and to educate common-law Francophone students outside Quebec in their own language. ${ }^{24}$

However, the great changes in the population of Canadian law faculties - and thus ultimately of the profession - were less the result of internal programmatic initiatives than of demography and a general increase in higher education participation rates. Post-war immigration to Canada gradually produced greater ethnic diversity first in undergraduate programmes, then in law schools, and ultimately in the profession. ${ }^{25}$ Women, who were on the way to comprising more than half of the undergraduate population in arts faculties, began to appear in increasing numbers in law schools. By 1993 they comprised 48 per cent of the population of Canadian law schools and 27 per cent of the legal profession. With some time delays, and after some controversy, women began to take their place in the legal academy: by 1993, 28 per cent of Canadian law teachers were women, and as of 1996-97, eight of the twenty-one serving deans of Canadian law schools were women. ${ }^{26}$

This is by no means to say that by the 1990 s, the democratization of entry into law schools was complete, or that the egalitarian principle had been fully accepted and implemented by the legal profession. As recent research attests, barriers to women and to racial and ethno-religious groups still remain in many professional settings. ${ }^{27}$ And race and class apparently continue to stunt the ambitions and prejudice the life chances of poor people

21 H. Arthurs, 'Progress and Professionalism: The Canadian Legal Profession in Transition' in Law and Social Change, ed. J. Ziegel (1972).

22 R. Bureau and C. Jobin, 'Les Sciences Juridiques à l'Université du Québec à Montréal: Fifteen Years Later' (1987) 11 Dalhousie Law J. 295.

23 Report of the Special Committee on Legal Education (the MacKinnon report) (1972).

24 R. Thompson, 'The University of Saskatchewan Native Law Centre' (1988) 11 Dalhousie Law J. 712. M. Bastarache, 'Teaching the Common Law in the French Language' (1983) 7 Dalhousie Law J. 348.

25 D. Stager with H. Arthurs, Lawyers in Canada (1990) at 143; J. Hagan, M. Huxter, P. Parker, 'Class Structure and Legal Practice: Inequality and Mobility Among Toronto Lawyers' (1988) 22 Law and Society Rev. 9.

26 Touchstones for Change: Equality, Diversity and Accountability (the Wilson report) (1993).

27 J. Hagan and F. Kay, "Changing Opportunities for Partnership for Men and Women Lawyers During the Transformation of the Modern Law Firm' (1994) 32 Osgoode Hall Law J. 413. 
and blacks who remain under-represented in tertiary education generally, and likely even more so in law schools and the legal profession. ${ }^{28}$

Moreover, the innate egalitarianism and moral fervour of Canadian law schools should not be overstated: to a large extent reformist and egalitarian initiatives were fuelled by the highly publicized American civil rights revolution of the 1950s and 1960s. In particular, the American experience inspired the adoption in 1982 of the Canadian Charter of Rights and Freedoms, and the Charter in turn transformed legal discourse and juridified politics. ${ }^{29} \mathrm{Law}$ schools have responded predictably: courses on constitutional law shifted their focus from federalism to Charter rights; new courses on civil and personal liberties proliferated; Charter themes appeared prominently in courses such as criminal law and administrative law; and legal journals sometimes seem concerned with little else. ${ }^{30}$ More to the point for present purposes, the definition and implementation of equality rights has become a central theme in the political economy of law faculties. Faculty members and students from equality-seeking groups and their sympathetic colleagues - women, gays, blacks, first nations, the disabled - have not only demanded access to legal education and to law teaching jobs; they have sought protection of their dignity and sensibilities within law schools through institutional guarantees and administrative structures; they have claimed recognition of their distinctive perspectives on law in the form of special courses and scholarly initiatives; and they have done all of this using not merely the conventional polite and impolite tactics of academic politics, but if needs be, the occasional threat of litigation as well. ${ }^{31}$

Much remains to be done; some institutions have changed less than others; but noticeable progress has been achieved mostly by means of strategies which were less formal and legally-based (and hopefully less vulnerable to

28 B. Mazer and M. Peeris, Access to Legal Education in Canada: Databook 1990; Report of the Special Committee of the Law Society of Upper Canada on Equity in Legal Education and Practice (1991); A. Timoll, Black Access to the Legal Profession: The Timoll Report to the Black Law Students Association and the Attorney General for Ontario (1996). However, the Wilson report, op. cit., n. 26, indicates that visible minority students in a sampling of law schools comprise 12 per cent of the graduating class as opposed to 6 per cent of Canada's overall population; for aboriginal students, the figures are 2 per cent as opposed to 2.3 per cent.

29 See, for example, D. Beatty, Talking Heads and the Supremes: The Canadian Production of Constitutional Review (1990); M. Mandel, The Charter of Rights and the Legalization of Politics in Canada (1994); A. Hutchinson, Waiting for Coraf: A Critique of Law and Rights (1995).

30 In the first edition of P.W. Hogg, Constitutional Law of Canada (1977), the leading Canadian text, section III covering materials on civil liberties took up 7 per cent; by the time of the fourth edition (1996), section III, covering materials on civil liberties and Charter issues, accounts for 41 per cent.

31 The broad sweep of these claims is captured in R. Devlin, 'Towards An/Other Legal Education: Some Critical and Tentative Proposals to Confront the Racism of Modern Legal Education' (1989) 38 University of New Brunswick Law J. 89; see also Wilson, op. cit., n. 27. 
reversal) than those adopted in the United States of America. On the other hand, progress has not been cost-free: law schools have faced choices explicit and tacit, real and imagined - between egalitarianism and meritocracy; the ensuing controversies have sometimes ruptured facultystudent and collegial relations; and sometimes the compromises adopted have been inauthentic, unsuccessful or morally untenable. And the cost of progress is likely to go up: choices are harder and harder to make in a law school economy of dwindling resources and in a labour market characterized by intense competition for scarce academic and professional jobs

\section{THE POLITICS OF KNOWLEDGE}

Reference has already been made to the early, not wholly successful, attempts at interdisciplinary scholarship and teaching in Canadian law schools in the 1960s, to the role of Law and Learning in helping to consolidate and legitimate this development in the early 1980 s, and to the subsequent momentum which has developed. In the early stages, interdisciplinarity consisted largely of attempts to provide a brief historical, sociological, economic or political background context for the discussion of conventional legal issues; over time, law professors actually tried their hand at historiography, empirical research or philosophy, though not always confidently or competently; and recently, law professors with advanced degrees in the humanities and social sciences have begun to produce interdisciplinary work of a higher standard.

The 'normalization' of law within the constellation of university disciplines obviously enriches the intellectual experience and contribution of Canadian law professors. However, it is also the source of considerable conflict. Law professors who prefer to continue to teach and write in the classic blackletter tradition sometimes resent and disparage their more adventurous colleagues; deans who feel pressure to staff 'core' courses or to respond to professional expectations of conventional scholarship, sometimes fail to support interdisciplinary initiatives; scholars in other disciplines do not always appreciate encroachments by their neighbours; and interdisciplinary scholars alienated by unsympathetic students, colleagues or administrators - and by the intrinsic difficulty of their task ${ }^{32}$ - sometimes become disillusioned and resentful. Nor does a shared commitment to interdisciplinarity necessarily create bonds amongst colleagues. In law, as in other disciplines, adherents of positivist social science, critical studies, econometrics, feminist, gay, and black studies, and postmodernism are often at war with each other and amongst themselves. ${ }^{33}$

But most importantly, interdisciplinarity represents - and to some extent

32 L. Salter and A. Hearn, Outside the Lines - Issues in Interdisciplinary Research (1997).

33 R. Macdonald, 'Office Politics' (1990) 40 University of Toronto Law J. 419. 
is intended to represent - a challenge to the very foundation of the Bar's wealth and power: professional knowledge. True, by allocating resources to teaching and research in specific fields previously ignored by practitioners, law schools helped to 'invent' new fields of professional practice, such as labour law, immigration and refugee law, family law, and civil liberties. But the academy's epistemic divergence from the Bar has itself engendered misunderstanding and mistrust, not least because interdisciplinary research has helped to diminish the influence and market value of conventional professional knowledge in automobile accident litigation, tax and regulatory regimes, patterns of judicial recruitment, and elsewhere.

Thus, the academy's role in rearranging the market for legal services has exacerbated resentment caused by the growing asymmetry between what lawyers and academics know about law and perceive as the essential elements of legal education and legal practise. Since divergences in professional knowledge have also become an important factor in the specialization, diversification, and stratification of the Bar - deepening existing fault lines of gender, class, and ethnicity, and confounding attempts to maintain professional solidarity and the institutions of professional governance $e^{34}-$ the academy's development and dissemination of 'new knowledge' is rightly perceived by the Bar as a divisive and threatening influence.

However, once again, Canadian law faculties should not be awarded undue credit for intellectual innovation: much - not all - of what has transpired in legal-intellectual circles is derived from, or in reaction to, familiar developments in the United States of America. As will be suggested below, American influence pervades Canadian social, political, and, especially, economic life. But law represents a special case even as compared with other policy disciplines which have similarly experienced 'globalization of the mind' ${ }^{35}$ The sheer size, virtuosity, variety, reputation, generosity, productivity, and power of the great American law schools has made them a 'finishing school' for a high proportion of Canadian law teachers, especially those from English-speaking provinces, and American academic literature - in particular, specialized and interdisciplinary publications - comprises a large part of the literature available to Canadian scholars. ${ }^{36}$

The dominance of Canadian law schools by American legal-academic culture, American social science, and American intellectual and political agendas more generally has by no means been entirely negative. Canada has borrowed (and sometimes improved upon) American legislation in areas such as collective bargaining, securities regulation, human rights,

$34 \mathrm{H}$. Arthurs, 'A Lot of Knowledge is a Dangerous Thing: Will the Legal Profession Survive the Knowledge Explosion?' (1995) 18 Dalhousie Law J. 295.

$35 \mathrm{H}$. Arthurs, 'Globalization of the Mind: Canadian Elites and the Restructuring of Legal Fields' (1998) Cdn. J. of Law and Society (forthcoming).

36 The Canadian Journal of Law and Society first appeared in 1986, twenty years after its United States counterpart, and there is still no Canadian equivalent of the Journal of Legal Education, published by the Association of American Law Schools, or of most of the specialist scholarly publications in law and adjacent disciplines which appear in the United States. 
environmental protection, and freedom of information. Emancipatory movements in Canada, which tend to draw strong support in law faculties, were often inspired by, and linked to, American movements. And Canadian scholars were able to exert increasing influence on law reform bodies, the Supreme Court and the practising Bar thanks in part to the reassuring example provided by their American counterparts. But all that said, the United States of America has a different history, different political institutions and values, different economic and social problems, a different sense of its own destiny as a hegemonic power. If Canadian legal scholarship is excessively influenced by American sources and strategies, if Canadian academics, practitioners, judges, and students act as carriers of American ideas and discourse, what is distinctive about Canadian institutions may be diminished, and Canada's integration into a continental legal regime, dominated by the United States of America, may become irreversible.

\section{LAW SCHOOLS IN CANADA'S NEW POLITICAL ECONOMY}

Most western, industrialized countries have been experiencing the combined effects of globalization, technological change, and the retreat from the welfare state. Canada is no exception. However, its encounters with the 'new economy' have been exacerbated by certain low-intensity but long-standing Canadian crises: America's physical proximity, massive direct investment, and increasing cultural hegemony; the resulting paucity of home-based entrepreneurs and investors, relative to Canada's size and GNP; the modesty of its social democratic programmes, even at their height; and the centrifugal effects of Quebec nationalism, western regional alienation, and their respective constitutional perspectives and politics. ${ }^{37}$ Both of legal education's two powerful suzerains - the legal profession and the higher education sector - are being transformed by these developments.

Higher education first. Almost all Canadian universities are public institutions. However, government grants have been moving down an increasingly steep gradient; students are having to pay higher fees (though still very modest compared to American private universities); and greater reliance on corporate donations, contracts, and 'partnerships' is being encouraged, even required, as a matter of government policy. ${ }^{38}$ These developments are the direct result of the neo-conservative agenda of reducing taxes, public expenditure, and the size of government, which seems to prevail

37 I have canvassed some of these ideas in a series of articles: 'Labour Law without the State?' (1996) 46 University of Toronto Law J. 1; "Mechanical Arts and Merchandise": Canadian Public Administration in the New Economy' (1997) 42 McGill Law J. 29; Arthurs, op. cit., n. 35.

38 Between 1981-82 and 1995-96, the share of university revenues attributable to government grants declined from 72.6 per cent to 61.1 per cent; student fees rose from 9.6 per cent to 16.8 per cent: donations and bequests rose from 4.6 per cent to 7.9 per cent; and sales of services and products also rose from 7.1 per cent to 8.7 per cent. Centre for Education Statistics, Statistics Canada, reported in K. Unland, 'Inflation Outpaces University Revenues' Globe and Mail, 6 August 1997, A6. 
in greater or lesser degree in most Canadian governments, regardless of their ostensible ideology. Potentially more dangerous to universities, though not yet dominant, is an anti-élite, anti-intellectual populism which is likely to express itself in demands to reduce funding for 'academic' activities in general and for research in particular, in the abolition of tenure and research leaves, in increased teaching loads, in enhanced transparency and attacks on traditional institutional autonomy, and in the ruthless translation of students into empowered 'customers' or 'consumers' of higher education, with economic and possibly legal power to force institutions to respond to their wishes. Universities are responding as best they can, but the predictable results of these pressures are already beginning to become clear.

Within their universities, law faculties find themselves in a somewhat ambiguous position. Because they were not yet firmly established during the expansionary period of the 1960 s, law schools tended to receive inadequate per capita grants for teaching. Because they have only begun fairly recently to take scholarship seriously - especially interdisciplinary scholarship - they generally do not attract large research grants. On the other hand, law schools have been experiencing rapidly rising unit costs: pedagogic innovations such as clinical legal education and student research assignments are labour intensive; new, specialized periodicals subscriptions strain library budgets; computing costs rise exponentially as new research technologies and administrative systems are brought on stream. And finally, because they tend to be small faculties, still often regarded as marginal by larger and betterestablished parts of the university, law schools have limited capacity to influence the increasingly strident debates over internal resource allocation.

On the other hand, law schools do have certain advantages. Despite a decline from the peak application years of the 1970s, most of them have so far been able to sustain both the size and quality of their enrolments. Because of their connection with the profession, they have been able to attract at least some financial support, though this may dwindle as the profession itself experiences serious dislocations. In response to policies which promote privatization and self-advancement, law faculties and the legal professoriate are sometimes able to find remunerative work - professional training for practitioners in the one case, consulting and private practice in the other. And because they have always been run 'on the cheap', law schools are able to adjust to their declining fortunes somewhat more easily than historically privileged faculties.

The future of the legal profession is more complicated, but no more optimistic. The globalization of production and financial markets, the advent of hemispheric free trade and the enlarged technical capacity for remote control of corporate functions appear to have intensified the consolidation of authority at the head offices of American-based transnational corporations. ${ }^{39}$ This consolidation in turn has resulted in narrower mandates

$39 \mathrm{H}$. Arthurs, 'The Hollowing out of Corporate Canada?' in Navigating through Globalizations: The Challenge to Institutions, eds. J. Jenson and B. Santos (tentative title, forthcoming, 1998). 
and diminished autonomy for their Canadian subsidiaries, in some cases the end of the Canadian company as a separate legal entity, increased resort to global rather than local capital markets, and the removal of various high value-added service functions from Canadian regional offices to the head offices of the parent firm. And of course, because service providers who support the work of Canadian subsidiaries are likely to feel the knock-on effects, Canada's leading metropolitan law firms may well be confronting the loss of their most important corporate clientele. Nor are they likely to recoup this loss by seeking business abroad, given the paucity of Canadianbased transnational companies on whose coat-tails to ride. Nor can they easily shift to an increased emphasis on regulatory law, given the considerable deregulation wrought by neo-conservative governments, or to litigation, given the notorious reluctance of sensible businesses to litigate and the inability of ordinary citizens to do so, phenomena which are verified by the exponential growth of alternative dispute resolution - itself an expanding area of practice, but not one which lies within the legal profession's monopoly. If they wish to continue to serve their present clientele in an increasingly globalized and deregulated economy, the most optimistic option for Canada's élite law firms is to seek integration either into foreign-based transnational law firms or into multi-disciplinary practices built around a small number of large consulting and accounting firms.

Prospects for other lawyers are equally daunting. Niche law firms and mid-sized partnerships will continue to provide legal services to small and middling businesses, no doubt, but the destiny of such businesses is to be absorbed into larger companies represented by other law firms. Collections and conveyancing - the staple services provided by solo practitioners and small law firms to working- and middle-class individuals - may well pass into the hands of computerized, franchised 'storefront' providers, as seems to be happening in the United States of America, or be made superfluous by legal reforms which enable people to do for themselves..$^{40}$ And legal practices based on criminal law, family law, and immigration and refugee law have been badly eroded by radical cuts in legal aid funding.

Moreover, these developments coincide with a particularly unpropitious historical moment. Lawyers, like other professionals and persons in authority, are being stripped of formal prerogatives and of the deference and respect they traditionally enjoyed; they are being held to higher levels of expertise, accountability, and cost effectiveness; and they are therefore being forced to make greater investments in their own training, in technical systems for delivering and monitoring client services and in insurance and professional regulatory machinery. At the same time, and for many of the same reasons, divisive tendencies have undermined formal and informal

40 These-developments are traced in somewhat more detail in H. Arthurs, 'Lawyering in Canada in the 21st Century' (1996) 15 Windsor Yearbook of Access to Justice 202. 
processes of professional governance and made it difficult to rally professional constituencies to any common cause or culture. ${ }^{41}$ And finally, given the extent of stratification within the legal profession, in large measure along socio-economic and ethnic lines, it is all too likely than that the negative consequences of all of these developments will - as always - come to rest first and most heavily on those who are most vulnerable, women lawyers and those from disadvantaged communities. ${ }^{42}$

If this is any thing like an accurate account of the near-future of the Canadian legal profession, it is clear that its political economy will change rapidly. The prestigious corporate firms will be unable to sustain their incomes, recruitment patterns, quality of practice, influence within the profession, and perhaps their very existence as independent entities. The medium sized firms and many specialists in the private and public sectors will be hard hit, though they may possibly find the means to adapt to the new situation. And the yeomanry of the profession - solo practitioners and small firms - will find themselves reduced to employment in the dark satanic mills of mass-production, franchised legal service providers, or be driven out of practice altogether.

The consequences for legal education are fairly predictable. Legal professions may well attempt to limit entry, by means licit and illicit; governments may decide to save money by closing law schools or reducing their intake; universities are likely to lack either the will or the resources to resist; some legal academics may become redundant; some law graduates may face unemployment or underemployment. But even if none of this were to actually happen, the new economy provides a hostile environment for both law professors and their students. Quite understandably, students have become very nervous about their future job prospects. Most try to make themselves more marketable by using their recently acquired power as 'consumers' to insist on courses, syllabuses, and pedagogies which, in their perception, reinforce their survival skills. As a corollary they are increasingly impatient, as a group, with 'humane professionalism', the ethos of Canadian law schools since the 1960s, and they increasingly exercise their right to avoid 'purely academic' offerings. ${ }^{43}$ And this brings them into direct conflict with their already beleaguered professors, who confront heavier work loads, more rigorous performance measures, declining financial prospects - and now, it seems likely, intellectual frustration.

How will law schools respond to this crisis of shrinking resources? Essentially they have only three options: to charge their students more; to seek new sources of revenue, especially from the profession; and to reduce

41 H. Arthurs, 'The Dead Parrot: Does Professional Self-Regulation Exhibit Vital Signs?' (1995) University of Alberta Law Rev. 800.

42 See Hagan et al., op. cit., n. 25; J. Hagan and F. Kay, Gender in Practice: A Study of Lawyers' Lives (1995).

43 Law and Learning, op. cit., n. 8, at pp. $47 \mathrm{ff}$. 
and impoverish their programmes. None of these is particularly attractive. Increased charges to students will threaten accessibility to legal education and practice, and reverse the trend to democratization of the profession. If the profession itself is suffering economically, it will be difficult for law schools to secure donations from law firms, or to enrol lawyers in profitgenerating programmes such as continuing legal education. And if law schools are forced to reduce their programmes, the first casualties are likely to be those perceived to be costly or peripheral to their educational mission or both: small interdisciplinary courses, graduate studies and research - the very initiatives mandated by Law and Learning.

\section{CONCLUSION}

The purpose of this essay has been less to persuade readers of impending doom - though doom may indeed impend - than to open up new and broader perspectives on legal education. Canadian law schools are addressing multiple crises and contestations. These have their origins not in the usual contrariness of university communities, nor in the recent and ongoing revolution of legal pedagogy and research, nor even in the ambiguous relations of legal academe with the practising bar. For the most part, they are outcroppings of the larger and deeper crises of Canada's troubled political economy. Thus, Canadian law professors confront an awful choice. Since they cannot do much about the real source of their discontents, should they focus scarce talents and energies on sustaining law schools as long as possible, by all expedient means including pandering to students and the profession, until better times arrive? Or should they commit their critical skills and intellectual talents to efforts to alter the larger political economy, despite the absence of institutions, processes and constructive strategies through which legal academics and other citizens can work for a brighter future? 